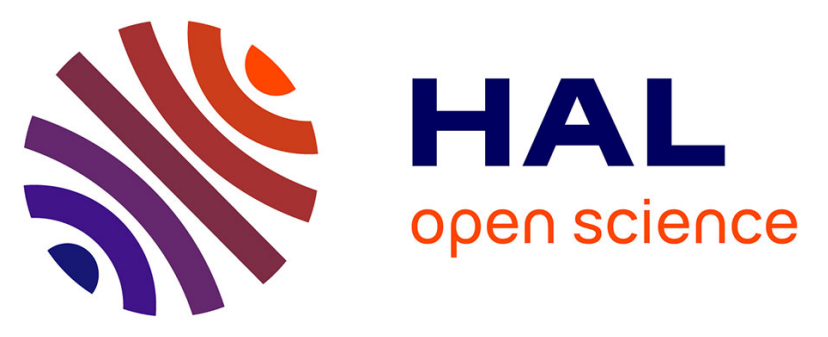

\title{
The same but different: stable isotopes reveal two distinguishable, yet similar, neighbouring food chains in a coral reef
}

Baptiste Lebourg, Yves Letourneur, Daniela Bănaru, Jean Blanchot, Cristele

Chevalier, Gérard Mou-Tham, Benoit Lebreton, M. Pagano

\section{To cite this version:}

Baptiste Lebourg, Yves Letourneur, Daniela Bănaru, Jean Blanchot, Cristele Chevalier, et al.. The same but different: stable isotopes reveal two distinguishable, yet similar, neighbouring food chains in a coral reef. Journal of the Marine Biological Association of the UK, 2018, 98 (7), pp.1589-1597. 10.1017/S0025315417001370 . hal-02015534

\author{
HAL Id: hal-02015534 \\ https://hal.science/hal-02015534
}

Submitted on 12 Feb 2019

HAL is a multi-disciplinary open access archive for the deposit and dissemination of scientific research documents, whether they are published or not. The documents may come from teaching and research institutions in France or abroad, or from public or private research centers.
L'archive ouverte pluridisciplinaire HAL, est destinée au dépôt et à la diffusion de documents scientifiques de niveau recherche, publiés ou non, émanant des établissements d'enseignement et de recherche français ou étrangers, des laboratoires publics ou privés. 


\title{
The same but different: stable isotopes reveal two distinguishable, yet similar, neighbouring food chains in a coral reef
}

\author{
baptiste le bourg ${ }^{1,2}$, yves letourneur ${ }^{3}$, daniela bánaru ${ }^{1}$, jean blanchot ${ }^{1}$, \\ cristéle chevalier ${ }^{1}$, gèrard mou-tham ${ }^{4}$, benoit lebreton ${ }^{5}$ and marc pagano ${ }^{1}$ \\ ${ }^{1}$ Aix Marseille Université, CNRS/INSU, IRD, Mediterranean Institute of Oceanography (MIO), UM 110, 13288 Marseille, France, \\ 'Université de Liège, Laboratory of Oceanology, MARE Centre, 4000 Liège, Belgium, ${ }^{3}$ Université de la Nouvelle-Calédonie, \\ Laboratoire LIVE and LABEX 'CORAIL', BP R4, 98851 Nouméa cedex, New Caledonia, ${ }^{4}$ Institut de Recherche pour le \\ Développement (IRD), Centre de Nouméa, 98848 Nouméa, New Caledonia, ${ }^{5}$ Université de La Rochelle, UMR CNRS 7266 LIENSs, \\ 17000 La Rochelle, France
}

\begin{abstract}
Stable isotope compositions were studied in particulate organic matter (POM), zooplankton and different trophic groups of teleosts to compare food chains based on plankton at two sites (lagoon and outer slope) in a New Caledonian coral reef. For each trophic compartment, $d^{13} \mathrm{C}$ values were always lower in the outer slope than in the lagoon. This result may be explained by potential differences in POM composition between the two environments, suggesting that the two food chains are based on different primary sources of carbon. In contrast, $d^{15} \mathrm{~N}$ values did not vary between the lagoon and the outer slope, indicating that these two food chains presented similar length and trophic levels, despite being distinguishable.
\end{abstract}

Keywords: barrier reef, particulate organic matter, zooplankton, reef teleosts, stable isotopes, Pacific Ocean

\section{INTRODUCTION}

Food webs encompass various food chains which structure marine communities. Variations in the relative importance of one component of a food chain (from nutrients to predators) may change abundances of the different species that are part of the food web (Friedlander \& DeMartini, 2002; Smith et al., 2010). Coral reefs are a habitat for numerous species and provide various ecological goods and services (Moberg \& Folk, 1999). Consequently, knowing the food web functioning of these habitats is critical for their management.

Coral reefs were formerly considered as food webs isolated in an oceanic desert. The surrounding ocean, however, is also an important food source for coral reefs, as oceanic zooplankton may be imported into the reef by waves and tidal currents, and then consumed by planktivorous teleosts (Hamner et al., 1988, 2007). While benthic sources represent an important carbon source to reef teleosts (Carassou et al., 2008; Wyatt et al., 2012; Briand et al., 2016), numerous species rely principally or exclusively on planktonic sources for food (Hobson, 1974; Frédérich et al., 2009) and even non-planktivorous species may rely on oceanic productivity (Wyatt et al., 2012). Barrier reefs act as border zones between oceanic and lagoon areas, leading to differences in habitat conditions (Delesalle \& Sournia, 1992; Leichter et al., 2013) and community composition (Carleton \& Doherty, 1998; Lecchini et al.,
2003; Leichter et al., 2013). Marked differences between food webs could thus be expected (Wyatt et al., 2012; Briand et al., 2015), as an indicator of water retention (Leichter et al., 2013) and of separation between neighbouring outer slope and lagoon communities.

Stable isotope analyses are commonly being used in food web studies. They offer a basis for studying food web components as stable isotope composition can be measured in most organisms, including photosynthetic ones, as well as in organic particles (e.g. Davenport \& Bax, 2002; Carassou et al., 2008). Carbon isotopic composition $\left(d^{13} \mathrm{C}\right)$ is generally used to determine the baseline sources of carbon in food webs (Michener \& Kaufman, 2007; Briand et al., 2015) because of the differences in stable isotope composition generally observed between the different types of primary producers (phytoplankton, phytobenthos) or organic matter and the low enrichment in ${ }^{13} \mathrm{C}(0.5-1 \%)$ in organisms relative to their diet (DeNiro \& Epstein, 1978; Michener \& Kaufman, 2007). Nitrogen isotopic composition $\left(d^{15} N\right)$ is used to estimate the trophic level of consumers, as organisms are generally enriched in ${ }^{15} \mathrm{~N}$ ('"'3.4\% on average) relative to their diet (DeNiro \& Epstein, 1981; Schoeninger \& DeNiro, 1984; Michener \& Kaufman, 2007) although important variations of the trophic enrichment from prey to predators occur (Wyatt et al., 2010). Furthermore, spatial and temporal variations of $d^{13} \mathrm{C}$ and $d^{15} \mathrm{~N}$ in the baseline sources of food webs and organisms (e.g. Harmelin-Vivien et al., 2008; Veit-Köhler et al., 2013) may help to identify feeding areas (Hobson, 1999).

In this study, the planktonic food chain of the southwestern New Caledonian coral reef environment was 
investigated by analysing $\mathrm{C}$ and $\mathrm{N}$ stable isotope ratios in particulate organic matter, two size classes of zooplankton and four trophic groups of teleosts. The chosen study area was the Ouano lagoon. Most studies on reef food webs of New Caledonia using stable isotopes were conducted in the Nouméa lagoon (e.g. Carassou et al., 2008; Briand et al., 2016) but the Ouano lagoon has not been studied, to our knowledge. Furthermore, analysis of the isotopic signatures of different size classes of plankton has not been done before on New Caledonian coral reefs. The aims of this study were (1) to identify the pathways of organic matter from sources to demersal zooplanktivorous teleosts through stable isotope analysis, (2) to compare the architecture of the two identified food chains between lagoon and outer slope assemblages.

\section{MATERIALS AND METHODS}

\section{Study area}

The Ouano lagoon (south-west of New Caledonia, Pacific Ocean; Figure 1) is delimited by a large barrier reef and comprises several islets and intermediate reefs within the lagoon, i.e. coral reefs located in the middle of the lagoon between the coastline and the barrier reef. It is connected to the external ocean by the St-Vincent pass (southern passage) and the Isié pass (northern passage). It has a mean depth of $10 \mathrm{~m}$. Previous studies have shown that water circulation in the Ouano lagoon is driven by both tide and waves (Chevalier et al., 2012, 2015): inward and outward flows of water through the passes occur during the flood and the ebb respectively. Oceanic water may also enter into the lagoon by going over the barrier reef during high wave events. The path of the lagoon water can be determined by the method of water origin (de Brye et al., 2013), with the numerical hydrodynamic model developed and validated in Chevalier et al. (2015). This method highlights that water near the barrier reef inside the lagoon is predominantly coming from the outer slope (Figure 1).

\section{Sampling}

Sampling was performed within the lagoon at '"'2 - 3 m depth and on the outer slope at '"'10-15 m depth from 2-9 October 2013. Particulate organic matter (POM) was considered as the baseline of the studied food chain as it included phytoplankton and other edible particles such as mucus, faeces and phytobenthos debris (Wyatt et al., 2013). POM was obtained by sampling and filtering seawater on pre-combusted (5008C, $2 \mathrm{~h}$ ) GF/F filters (N 1/4 25). These filters were dried (608C, $48 \mathrm{~h}$ ) prior to subsequent analysis. Zooplankton was sampled at "''330 m on the outer slope and '"' $4 \mathrm{~m}$ in the lagoon and was sampled horizontally to obtain more biomass, by using an $80 \mathrm{~mm}$ mesh-sized WP2 net (N 1/4 3). Zooplankton samples were separated into two size classes $(80-200$ and $\geq 200 \mathrm{~mm})$ using sieves and then freeze-dried. Teleosts were opportunistically collected using $7 \%$ rotenone or by spearfishing inside the lagoon and on the outer slope (Figure 1) and then were frozen. In the laboratory, species were identified and classified in trophic groups according to the origin of their food given in the literature (Supplementary Table S1 in the supplemental material section): diurnal planktivorous teleosts feeding on pelagic plankton; nocturnal planktivorous teleosts feeding at night; non-planktivorous teleosts feeding on benthic prey (phytobenthos, sessile and/or mobile invertebrates) and teleosts with a mixed diet feeding on both pelagic and benthic food (e.g. consumption of both phytobenthos and planktonic crustaceans). Total length ( $T L$ ) was measured. Digestive tracts of teleosts were removed and preserved in 958 ethanol. Anterior dorsal muscles of teleosts were sampled and freezedried for subsequent stable isotope analyses.

\section{Stable isotope analysis}

Zooplankton and teleost samples were ground into a fine powder. Carbonates present in POM and zooplankton (i.e. crustacean carapaces, mollusc shells) are more enriched in ${ }^{13} \mathrm{C}$ than other tissues (DeNiro \& Epstein, 1978). Consequently, analyses were carried out separately for measurements of $d^{13} \mathrm{C}$ and $\mathrm{d}^{15} \mathrm{~N}$ values. For $\mathrm{d}^{13} \mathrm{C}$ measurements,

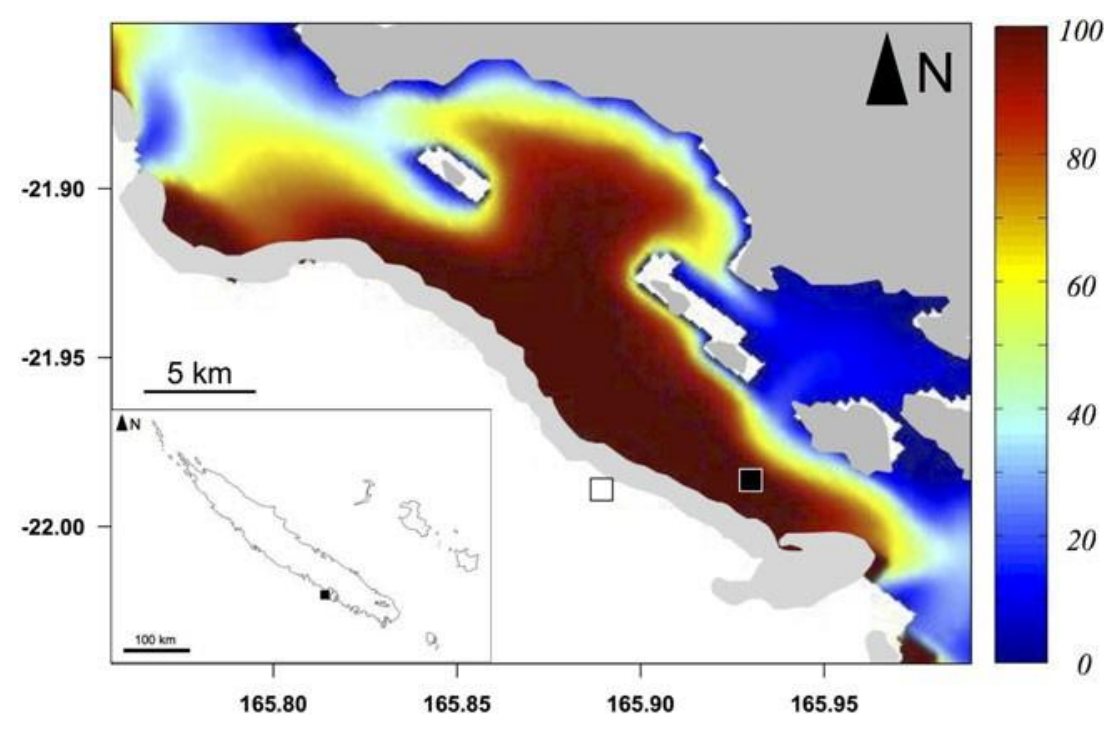

Fig. 1. Sampling area (light grey: reefs) of particulate organic matter (POM) and zooplankton and sampling stations of teleosts inside the Ouano lagoon (black square) and on the outer slope (white square). Colours represent the percentage of water coming from the outer slope in the Ouano lagoon with a wave height of $0.3 \mathrm{~m}$, i.e. the mean wave height during the sampling campaign. 
one half of POM samples and one half of each zooplankton sample received $1 \% \mathrm{HCl}$ treatment before being rinsed and dried to remove carbonates (Kennedy et al., 2005; Jaschinski et al., 2008; Kolasinski et al., 2008). For $d^{15} \mathrm{~N}$ measurements, the rest of the raw samples was analysed without acidification as acidification may affect nitrogen isotopic composition (Bunn et al., 1995; Kennedy et al., 2005; Kolasinski et al., 2008). Six replicates were analysed per station for POM and per zooplankton sample (three for $d^{13} \mathrm{C}$, three for $d^{15} \mathrm{~N}$ ). For teleosts, a maximum of nine individuals (three individuals selected in three size classes) per species available were selected for stable isotope analysis. Lipid removal or correction for $\mathrm{d}^{13} \mathrm{C}$ values was not necessary as levels of lipids in teleosts were low (C/N , 3.5) (Post et al., 2007; Skinner et al., 2016).

Powdered samples were precisely weighed ('"'0.4 mg for non-acidified zooplankton and teleosts; $1 \mathrm{mg}$ for non-acidified POM and $2 \mathrm{mg}$ for acidified POM and zooplankton; precision of $0.01 \mathrm{mg}$ ) in $5 \times 8$ tin cups ( 6 cups per station for POM and per zooplankton sample), and analysed with an elemental analyser (Flash EA 1112, Thermo Scientific, Milan, Italy) coupled to a continuous-flow isotope-ratio mass spectrometer (Delta $\mathrm{V}$ Advantage with a Conflo IV interface, Thermo Scientific, Bremen Germany). Analyses were conducted at the LIENSs stable isotope facility at the University of La Rochelle, France. $\mathrm{d}^{13} \mathrm{C}$ and $\mathrm{d}^{15} \mathrm{~N}$ values are expressed in d notation in \%o as deviations from standards (Vienna Pee Dee Belemnite for $d^{13} \mathrm{C}$ and $N_{2}$ in air for $d^{15} N$ ) according to the formula $d X_{\text {sample }} 1 / 4$ $\left[\left(R_{\text {sample }} / R_{\text {standard }}\right) 21\right] \times 1000$, where $X$ is ${ }^{13} \mathrm{C}$ or ${ }^{15} \mathrm{~N}$, $R_{\text {sample }}$ is the isotopic ratio of the sample and $R_{\text {standard }}$ is the isotopic ratio of the standard. Calibration was done using reference materials (USGS-24, IAEA-CH6, -600 for carbon; IAEA-N2, -NO-3, -600 for nitrogen). Analytical precision was , $0.15 \%$ based on the analyses of acetanilide (Thermo Scientific) used as laboratory internal standard.

\section{Stomach content analysis}

Stomach contents of teleosts from the outer slope were analysed and the food items were identified to the lowest feasible taxonomic level. A technical failure prevented the analysis of the stomach contents of teleosts sampled inside the lagoon. Dry weight (DW) of ingested organisms was measured or estimated from data or mathematical formulas available in the literature (e.g. Uye, 1982; Chisholm \& Roff, 1990; Satapoomin, 1999). Consequently, for some prey, total length and cephalosome length were measured to estimate DW. Food composition was expressed by frequency of occurrence $(\% \mathrm{O}$; percentage of nonempty stomachs containing a given prey item), numerical percentage $(\% \mathrm{~N}$; mean percentage per stomach of the number of a given prey item as a proportion of the total number of all prey in each stomach), weight percentage (\%W; mean percentage per stomach of the weight of a given prey item as a proportion of the total weight of all prey in each stomach). The index of relative importance (IRI; Pinkas et al., 1971) for each prey item was then calculated according to the formula IRI $1 / 4 \% O \times$ $(\% \mathrm{~N}+\% \mathrm{~W})$, and then transformed into percentage by dividing it by the sum of IRI for all prey items (\%IRI; Cortés, 1997).

\section{Data analysis}

Data analyses were performed with the $\mathrm{R}$ statistical software (version 2.15.0; R core team, 2013). Isotopic compositions were analysed separately on POM, zooplankton and teleosts.
Differences in $d^{13} \mathrm{C}$ and $d^{15} \mathrm{~N}$ values in POM inside the lagoon and on the outer slope were compared with Student's t-tests as data were normally distributed. After checking normality of residuals (Shapiro test) and homoscedasticity (Levene test), type III ANOVA were performed to compare $d^{13} \mathrm{C}$ and $d^{15} \mathrm{~N}$ values among the fixed factors sampling zones (lagoon and outer slope) and size classes of zooplankton $(80-200$ and $\geq 200 \mathrm{~mm})$. Both factors were orthogonal with each other.

For teleosts, after checking normality of residuals (Shapiro test) and homoscedasticity (Levene test), type III ANCOVA were performed to compare $d^{13} \mathrm{C}$ and $d^{15} \mathrm{~N}$ values among the fixed factors trophic groups (diurnal planktivorous; nocturnal planktivorous; non-planktivorous and mixed diet) and sampling zones (lagoon and outer slope), with total body length as a co-variable to account for any size effect. Both factors were however not orthogonal with each other. Consequently, post hoc Games - Howell tests were performed if trophic groups had a significant effect on isotopic ratios. Hierarchical clustering (Euclidean distance, Ward method) was also performed to compare isotopic ratios among species. Trophic levels of the different trophic groups of teleosts were calculated using the formula proposed by Post (2002): Trophic level $1 / 42+\left(d^{15} N_{\text {trophic }}\right.$ group $\left.2 d^{15} N_{\text {Zoo }=200}\right) / 3.4$. $\mathrm{d}^{15} \mathrm{~N}_{\text {trophic group }}$ is the mean $\mathrm{d}^{15} \mathrm{~N}$ value of the trophic group considered in the lagoon or on the outer slope. $d^{15} N_{z o 0}=200$ is the mean $d^{15} \mathrm{~N}$ value in the zooplankton larger than $200 \mathrm{~mm}$ sampled in the lagoon or on the outer slope. $\mathrm{d}^{15} \mathrm{~N}$ value in the zooplankton larger than $200 \mathrm{~mm}$ was chosen as stomach contents showed that teleosts fed mainly on prey larger than $200 \mathrm{~mm}$ (mean + SD 1/4 $1016.3+0.7 \mathrm{~mm}$ ).

\section{RE SU LTS}

POM had a lower $d^{13} \mathrm{C}$ on the outer slope (mean + SD $1 / 4222.5+0.4 \%$ ) than inside the lagoon $(221.0+$ $1.5 \%$ o) (t $\left.1 / 422.814, \mathrm{P}^{1} / 40.020\right)$ but $\mathrm{d}^{15} \mathrm{~N}$ values did not significantly differ between the two zones (t $1 / 420.639, P 1 / 4$ 0.534) (Figure 2, Table 1).

In zooplankton, $d^{13} \mathrm{C}$ values were not influenced by size class but were significantly lower on the outer slope $(220.4+0.3 \%$ o $)$ than inside the lagoon $(219.0+\geq 0.0 \%$ o (Figure 2, Tables 1 and 2(a)). For $\mathrm{d}^{15} \mathrm{~N}$ values, there was a significant interaction between size class and zone, with higher values for small zooplankton inside the lagoon and for large zooplankton on the outer slope (Figure 2, Tables 1 and 2(b)).

ANCOVA results (Table 3(a)) showed that the interaction between sampling zone and trophic group influenced $\mathrm{d}^{13} \mathrm{C}$ values. This just significant interaction showed that the effect of the lagoon was slightly more important in some teleost trophic groups, but, as for POM and zooplankton, teleosts of all groups sampled on the outer slope had lower $d^{13} \mathrm{C}$ $(217.9+1.2 \%)$ than those sampled in the lagoon $(214.8+$ $2.4 \%$ ). The trophic group also influenced $\mathrm{d}^{13} \mathrm{C}$ but Figure 2 shows that trophic groups have rather similar values on the outer slope and more different ones inside the lagoon, in accordance with the interaction between the trophic groups and the sampling zone. Length had no effect on $d^{13} \mathrm{C}$.

ANCOVA results (Table $3(b))$ showed that $d^{15} \mathrm{~N}$ values were not influenced by the interaction between sampling zone and trophic group. There were also no significant difference in mean $\mathrm{d}^{15} \mathrm{~N}$ values between teleosts sampled inside the 


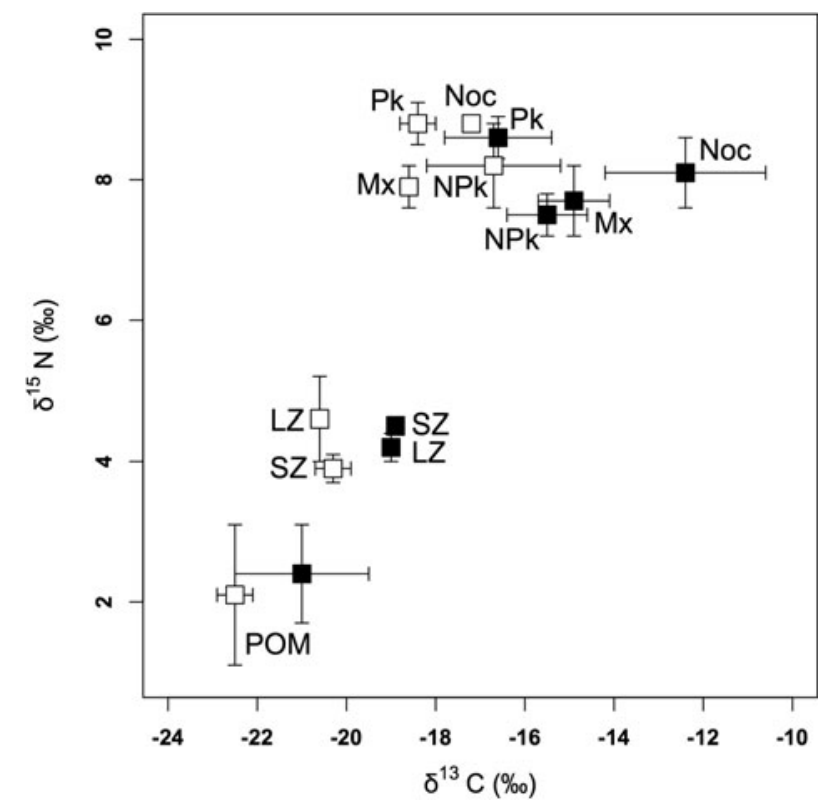

Fig. 2. Means and standard deviations of $d^{13} \mathrm{C}$ and $d^{15} \mathrm{~N}$ in the different groups of organisms inside the Ouano lagoon (black squares) and on the outer slope (white squares). SZ: $80-200 \mathrm{~mm}$ zooplankton; LZ: - $200 \mathrm{~mm}$ zooplankton; Pk: diurnal planktivorous teleosts; Noc: nocturnal planktivorous teleosts; NPk: non-planktivorous teleosts; Mx: teleosts with a mixed diet.

lagoon $(8.3+0.6 \%)$ and those sampled on the outer slope $(8.5+0.5 \%)$. The trophic group influenced $\mathrm{d}^{15} \mathrm{~N}$ values with diurnal planktivorous being the most ${ }^{15} \mathrm{~N}$-enriched teleosts among all trophic groups $(4.374 \leq t \leq 5.552 ; P, 0.01)$ while the $d^{15} \mathrm{~N}$ values of nocturnal planktivorous teleosts, non-planktivorous teleosts and teleosts with a mixed diet are not significantly different $(0.737 \leq t \leq 51.842 ; P$ - 0.05$)$. Length had a nearly significant effect on $d^{15} \mathrm{~N}$ because of increasing values of $d^{15} \mathrm{~N}$ with length in nocturnal planktivorous teleosts sampled inside the lagoon and non-planktivorous teleosts.

The cluster analysis on isotopic values (Figure 3) indicated that trophic group and zone of sampling influenced isotopic values in teleosts, as highlighted by the ANCOVA results. Three clusters appeared. The first one contained essentially non-planktivorous teleosts, including all those sampled inside the lagoon, but also contained a sub-cluster of nocturnal species. The second cluster contained only nocturnal species with a high $d^{13} \mathrm{C}$. The last cluster contained nearly all diurnal planktivorous species and is divided into two subclusters, one containing almost exclusively diurnal planktivorous teleosts sampled on the outer slope.

Diurnal planktivorous teleosts had the highest trophic level (3.29 in the lagoon and 3.24 on the outer slope), followed by the nocturnal planktivorous (3.15 in the lagoon and 3.24 on the outer slope), the non-planktivorous (2.97 in the lagoon and 3.06 on the outer slope) and the teleosts with a mixed diet (3.03 in the lagoon and 2.97 on the outer slope).

Stomach contents of teleosts sampled on the outer slope are summarized in Supplementary Table S2. Diurnal planktivorous teleosts fed on gastropod larvae (\%IRI $1 / 432.50$ ), phytobenthos (\%IRI $1 / 423.07$ ) and various copepod species (\%IRI $1 / 420.67$ ). The importance of phytobenthos for this group is explained by the consumption of this food by Genicanthus watanabei (\%IRI 1/484.55), which constitutes '"' a quarter of stomach contents of analysed planktivorous teleosts on the outer slope, while consumption of phytobenthos was negligible in the other planktivorous species (\%IRI, 5$)$. Non-planktivorous teleosts fed on phytobenthos (\%IRI $1 / 4$ 45.41), polyps (\%IRI $1 / 419.24$ ), benthic gastropods ( $\%$ IRI $1 / 4$ 13.79 ) and eggs (\%IRI $1 / 410.03)$. The number of analysed individuals, however, was rather low (Supplementary Table S2). Nocturnal planktivorous teleosts and teleosts with a mixed diet were both represented by a single species (Ostorhinchus angustatus and Pomacentrus brachialis respectively) and few

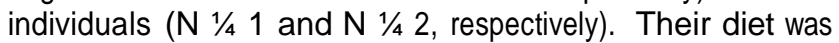
composed of five amphipods (\%IRI $1 / 483.19$ ) and one small shrimp (\%IRI $1 / 416.81)$ for Ostorhinchus angustatus and of copepods (mainly the genus Oncaea and Clauso/ Paracalanus, \%IRI 1/450.68), gastropod larvae (\%IRI $1 / 4$ 18.14) and Rhabdonema diatoms (\%IRI 1/4 18.06) for Pomacentrus brachialis.

\section{DISCUSSION}

\section{Differences and similarities between two neighbouring food chains}

Stable isotope analysis revealed that both food chains sampled in the Ouano lagoon and on the outer slope are distinguishable despite being close to each other (less than $10 \mathrm{~km}$ ) and despite an important part of the water in the lagoon coming from the outer slope. For each trophic compartment (i.e. POM, zooplankton size classes and different teleost trophic groups), $d^{13} \mathrm{C}$ values were significantly higher in the lagoon than on the outer slope despite both areas being close (less than $10 \mathrm{~km}$ ) while $\mathrm{d}^{15} \mathrm{~N}$ was not influenced by the sampling zone.

Differences in $d^{13} \mathrm{C}$ values between the lagoon and the outer slope may be explained by two hypotheses regarding POM composition. Firstly, $d^{13} \mathrm{C}$ values may be linked to potential differences in primary producer compositions between these two zones, namely by differences within picocyanobacteria assemblages that are important components in the oligotrophic ocean. In the Nouméa lagoon ('"'60 km south-east of Ouano lagoon), Prochlorococcus was shown to be dominant in oceanic waters, while Prochlorococcus and Synechococcus co-occur in the lagoon (Jacquet et al., 2006). Differences in $\mathrm{d}^{13} \mathrm{C}$ values linked to potential co-existence of Prochlorococcus and Synechococcus in the Ouano lagoon seem to indicate that water exchanges between lagoon and ocean do not lead to the homogenization of the community structure of phytoplankton at a large spatial scale because of quick renewal of water inside the Ouano lagoon and grazing of imported picophytoplankton by coral reef community (Houlbrèque et al., 2006; Cuet et al., 2011). Therefore, few picophytoplankton cells may be imported from the bordering ocean inside the lagoon by water passing over the reef. Further studies on phytoplankton communities of the Ouano lagoon may confirm this hypothesis.

Secondly, different contributions of materials (mucus, faeces, zooplankton, marine photosynthetic organism debris, barrier reef erosion debris) to POM among sites may explain the differences in $\mathrm{d}^{13} \mathrm{C}$ values between the lagoon and the outer slope (Wyatt et al., 2013; Briand et al., 2015). Wyatt et al. (2013) observed that allochthonous 
Table 1. $\mathrm{d}^{13} \mathrm{C}$ and $\mathrm{d}^{15} \mathrm{~N}$ values (mean $+\mathrm{SD}, \%$ ) of the trophic groups and species of teleosts.

\begin{tabular}{|c|c|c|c|c|c|c|c|c|c|c|}
\hline & \multicolumn{5}{|c|}{ Lagoon } & \multicolumn{5}{|c|}{ Outer slope } \\
\hline & $\mathrm{N}$ & $\begin{array}{l}\text { Length } \\
\text { range }(\mathrm{cm})\end{array}$ & $d^{13} C$ & $d^{15} N$ & $\begin{array}{l}\text { Trophic } \\
\text { level }\end{array}$ & $\mathrm{N}$ & $\begin{array}{l}\text { Length } \\
\text { range }(\mathrm{cm})\end{array}$ & $d^{13} C$ & $d^{15} N$ & $\begin{array}{c}\text { Trophic } \\
\text { level }\end{array}$ \\
\hline Particulate organic matter & 9 & NA & $221.0+1.5$ & $2.4+0.7$ & - & 6 & NA & $222.5+0.4$ & $2.1+1.0$ & - \\
\hline Zooplankton 80-200 mm & 3 & NA & $217.8+0.1$ & $4.5+0.1$ & - & 6 & NA & $219.6+0.5$ & $3.9+0.2$ & - \\
\hline Zooplankton - 200 mm & 3 & NA & $216.6+0.3$ & $4.2+0.2$ & - & 6 & NA & $218.7+0.1$ & $4.6+0.6$ & - \\
\hline Diurnal planktivorous & 32 & $3.5-21.0$ & $216.6+1.2$ & $8.6+0.3$ & 3.29 & 22 & $5.2-27.0$ & $218.4+0.4$ & $8.8+0.3$ & 3.24 \\
\hline Abudefduf sexfasciatus & 1 & 14.8 & 217.1 & 8.2 & 3.18 & 2 & $14.4-14.5$ & $218.0+0.5$ & $8.8+-0.0$ & 3.24 \\
\hline Acanthurus albipectoralis & 1 & 21.0 & 216.8 & 9.1 & 3.44 & 3 & $22.7-27.0$ & $218.1+0.5$ & $8.5+0.4$ & 3.15 \\
\hline Chromis margaritifer & - & - & - & - & - & 5 & $6.5-17.0$ & $218.5+0.2$ & $8.7+0.1$ & 3.21 \\
\hline Chromis vanderbilti & - & - & - & - & - & 2 & $5.2-5.9$ & $218.8+0.3$ & $8.4+0.5$ & 3.12 \\
\hline Chromis viridis & 9 & $3.7-10.8$ & $218.0+0.3$ & $8.6+0.3$ & 3.29 & - & - & - & - & - \\
\hline Dascyllus aruanus & 9 & $3.5-7.0$ & $215.1+0.6$ & $8.4+0.1$ & 3.24 & - & - & - & - & - \\
\hline Dascyllus reticulatus & 9 & $4.2-9.0$ & $216.6+0.5$ & $9.0+0.2$ & 3.41 & - & - & - & - & - \\
\hline Dascyllus trimaculatus & 3 & $6.5-11.5$ & $216.9+0.7$ & $8.6+0.3$ & 3.29 & - & - & - & - & - \\
\hline Genicanthus watanabei & - & - & - & - & - & 6 & $10.3-17.5$ & $218.1+0.4$ & $9.0+0.2$ & 3.29 \\
\hline Hemitaurichthys polylepis & - & - & - & - & - & 1 & 9.8 & 218.6 & 9.4 & 3.41 \\
\hline $\begin{array}{l}\text { Pseudanthias } \\
\text { squamipinnis }\end{array}$ & - & - & - & - & - & 3 & $11.3-19.8$ & $219.0+-0.0$ & $8.9+0.2$ & 3.26 \\
\hline Nocturnal planktivorous & 26 & $5.3-11.4$ & $212.4+1.8$ & $8.1+0.5$ & 3.15 & 1 & 29.1 & 217.2 & 8.8 & 3.24 \\
\hline $\begin{array}{l}\text { Cheilodipterus } \\
\text { quinquelineatus }\end{array}$ & 4 & $8.2-9.9$ & $211.0+0.4$ & $8.2+0.2$ & 3.18 & - & - & - & - & - \\
\hline Nectamia bandanensis & 6 & $5.5-8.7$ & $214.8+0.6$ & $8.3+0.1$ & 3.21 & - & - & - & - & - \\
\hline Ostorhinchus angustatus & - & - & - & - & - & 1 & 29.1 & 217.2 & 8.8 & 3.24 \\
\hline Ostorhinchus aureus & 2 & $10.1-11.4$ & $214.5+0.2$ & $9.0+0.1$ & 3.41 & - & - & - & - & - \\
\hline Ostorhinchus cyanosoma & 3 & $5.3-5.7$ & $212.0+0.4$ & $7.9+0.4$ & 3.09 & - & - & - & - & - \\
\hline $\begin{array}{l}\text { Ostorhinchus } \\
\text { novemfasciatus }\end{array}$ & 1 & 7.4 & 214.4 & 8.2 & 3.18 & - & - & - & - & - \\
\hline Pristiapogon exostigma & 9 & $6.6-9.3$ & $210.9+0.7$ & $7.8+0.6$ & 3.06 & - & - & - & - & - \\
\hline Pristiapogon kallopterus & 19. & .5 & $212.6 \quad 8$. & $.3 \quad 3.2$ & .21 & - & & - & & - Non- \\
\hline planktivorous & 5 & $4.4-13.5$ & $215.5+0.9$ & $7.5+0.3$ & 2.97 & 11 & $5.6-14.5$ & $216.7+1.5$ & $8.2+0.6$ & 3.06 \\
\hline Chrysiptera taupou & 2 & $4.4-6.3$ & $216.1+0.7$ & $7.1+0.2$ & 2.85 & - & - & - & - & - \\
\hline Forcipiger fiavissimus & - & - & - & - & - & 2 & $13.9-14.5$ & $217.1+-0.0$ & $8.9+1.2$ & 3.26 \\
\hline Neoglyphidodon melas & 1 & 13.5 & 216.2 & 7.8 & 3.06 & - & - & - & - & - \\
\hline Plectroglyphidodon dickii & - & - & - & - & - & 1 & 7.1 & 215.4 & 8.5 & 3.15 \\
\hline $\begin{array}{l}\text { Plectroglyphidodon } \\
\text { johnstonianus }\end{array}$ & - & - & - & - & - & 4 & $5.6-14.1$ & $215.3+0.3$ & $8.0+0.5$ & 3.00 \\
\hline $\begin{array}{l}\text { Plectroglyphidodon } \\
\text { lacrymatus }\end{array}$ & 1 & 6.4 & 214.5 & 7.7 & 3.03 & - & - & - & - & \\
\hline Pomacentrus wardi & - & - & - & - & - & 3 & $6.0-8.6$ & $218.5+0.3$ & $7.9+0.3$ & 2.97 \\
\hline $\begin{array}{l}\text { Pseudocheilinus } \\
\text { hexataenia }\end{array}$ & - & - & - & - & - & 1 & 5.6 & 217.5 & 8.4 & 3.12 \\
\hline Stegastes nigricans & 1 & 8.4 & 214.6 & 7.5 & 2.97 & - & - & - & - & - \\
\hline Mixed diet & 5 & $4.5-11.2$ & $214.9+0.8$ & $7.7+0.5$ & 3.03 & 2 & 9.2 & $218.6+0.2$ & $7.9+0.3$ & 2.97 \\
\hline Amphiprion akindynos & 1 & 11.2 & 215.9 & 8.5 & 3.26 & - & - & - & - & - \\
\hline Pomacentrus amboinensis & 1 & 9.3 & 214.1 & 7.2 & 2.88 & - & - & - & - & - \\
\hline Pomacentrus brachialis & - & - & - & - & - & 2 & 9.2 & $218.6+0.2$ & $7.9+0.3$ & 2.97 \\
\hline Pomacentrus moluccensis & 3 & $4.5-8.0$ & $214.9+0.6$ & $7.7+0.1$ & 3.03 & - & - & - & - & - \\
\hline
\end{tabular}

phytoplankton mainly contributed to POM near the reef crest at Ningaloo Reef ('"'40 - 75\%), while inside the lagoon autochthonous releases, i.e. detritus, mainly contributed to POM despite phytoplankton contribution remaining important ('"'20 - 25\%). Detritus may include, for example, sedimentary matter resuspended by cross-reef flows (Chevalier et al., 2015), phytobenthos debris and coral mucus (Wyatt et al., 2013), and are known to be more enriched in ${ }^{13} \mathrm{C}$ than phytoplankton (Wyatt et al., 2013; Briand et al., 2015).

Similar results were found at Ningaloo Reef, Western Australia, where $d^{13} \mathrm{C}$ values of POM were lower on the outer slope than in the lagoon while no spatial variations of $\mathrm{d}^{15} \mathrm{~N}$ occurred (Wyatt et al., 2013). In contrast, the inverse phenomenon was observed in two neighbouring bays of
Moorea Island (French Polynesia), with $\mathrm{d}^{13} \mathrm{C}$ values of POM decreasing from the entrance of the bays to the coastal areas (Letourneur et al., 2013). This difference may be explained by the lack of river inputs in the Ouano lagoon and the Ningaloo Reef (Wyatt et al., 2012, 2013) while the two bays of Moorea island are subjected to river inputs reducing $d^{13} \mathrm{C}$ of POM (Letourneur et al., 2013).

Spatial variations of stable isotope values in zooplankton followed the same trend as in POM. Higher or similar densities of zooplankton were observed in lagoons of New Caledonia than on outer slopes, with highest densities observed in coastal areas (Champalbert, 1993). Planktivorous teleosts, however, are known to form a 'wall of mouths' over reef flats that reduce the density and 
Table 2. Influence of size class (smaller or larger than $200 \mathrm{~mm}$ ) and zone of sampling (interior, outer slope) on (a) $d^{13} \mathrm{C}$ and (b) $d^{15} \mathrm{~N}$ values of zooplankton.

\begin{tabular}{lrrrr}
\hline & Df & MS & F & P \\
\hline (a) & 1 & 0.10 & 1.069 & 0.319 \\
Size class & 1 & 9.00 & 120.872 & $<0.001$ \\
Zone & 1 & 0.00 & 0.623 & 0.443 \\
Size class $\times$ Zone & 14 & 0.07 & & \\
Residuals & & & & \\
(b) & 1 & 0.16 & 0.970 & 0.341 \\
Size class & 1 & 0.04 & 0.243 & 0.63 \\
Zone & 1 & 1.14 & 7.133 & 0.018 \\
Size class 3 zone & 14 & 0.15 & & \\
Residuals & & & & \\
\hline
\end{tabular}

Bold results are significant.

biomass of zooplankton entering lagoons (Hamner et al., $1988,2007)$. Consequently, zooplankton in the Ouano lagoon may be mainly reef-produced. As a result, differences of zooplankton composition between the lagoon and the outer slope may occur (Champalbert, 1993; Hamner et al., 2007), contributing to stable isotope values differentiation between the two communities. Differences of stable isotope ratios between zooplankton from the lagoon and from the outer slope may also be explained by differences of trophic ecology. Detritus in the POM of the lagoon can be used as food by organisms, including zooplankton (Gottfried \& Roman, 1983; Crossman et al., 2001; Dromard et al., 2013). For example, Roman et al. (1990) showed that consumption of phytoplankton by reef zooplankton does not satisfy their daily nutritional requirements, leading reef zooplankton to also consume edible detritus such as mucus (Gottfried \& Roman, 1983). As a result, zooplankton in the lagoon and on the outer slope may exploit distinct food sources, i.e. differently composed POM, probably leading to their different $\mathrm{d}^{13} \mathrm{C}$ values.

\section{Trophic ecology of teleosts}

The differences in $d^{13} \mathrm{C}$ values between lagoon and outer slope in teleosts were noticeable and consistent with the spatial variations observed in POM and zooplankton, indicating that

Table 3. Influence of trophic group (diurnal planktivorous, nocturnal planktivorous, non-planktivorous and mixed diet) and zone of sampling (interior, outer slope) on (a) $d^{13} \mathrm{C}$ and (b) $d^{15} \mathrm{~N}$ values of teleosts.

\begin{tabular}{lrrrr}
\hline & Df & MS & \multicolumn{1}{c}{$F$} & \multicolumn{1}{c}{$P$} \\
\hline (a) & 1 & 0.00 & 0.001 & 0.974 \\
Body length & 3 & 14.10 & 8.618 & $<0.001$ \\
Trophic group & 1 & 49.56 & 30.287 & $<0.001$ \\
Zone & 3 & 4.46 & 2.732 & 0.049 \\
Trophic group 3 zone & 95 & 11.10 & & \\
Residuals & & & & \\
(b) & 1 & 0.59 & 3.456 & 0.066 \\
Body length & 3 & 3.36 & 19.545 & $<0.001$ \\
Trophic group & 1 & 0.40 & 2.327 & 0.130 \\
Zone & 3 & 0.42 & 2.438 & 0.069 \\
Trophic group $\times$ zone & 95 & 117 & & \\
Recidi ılc & & & & \\
\hline Bold resllt a & & & & \\
\hline
\end{tabular}

Bold results are significant.
Euclidean distance

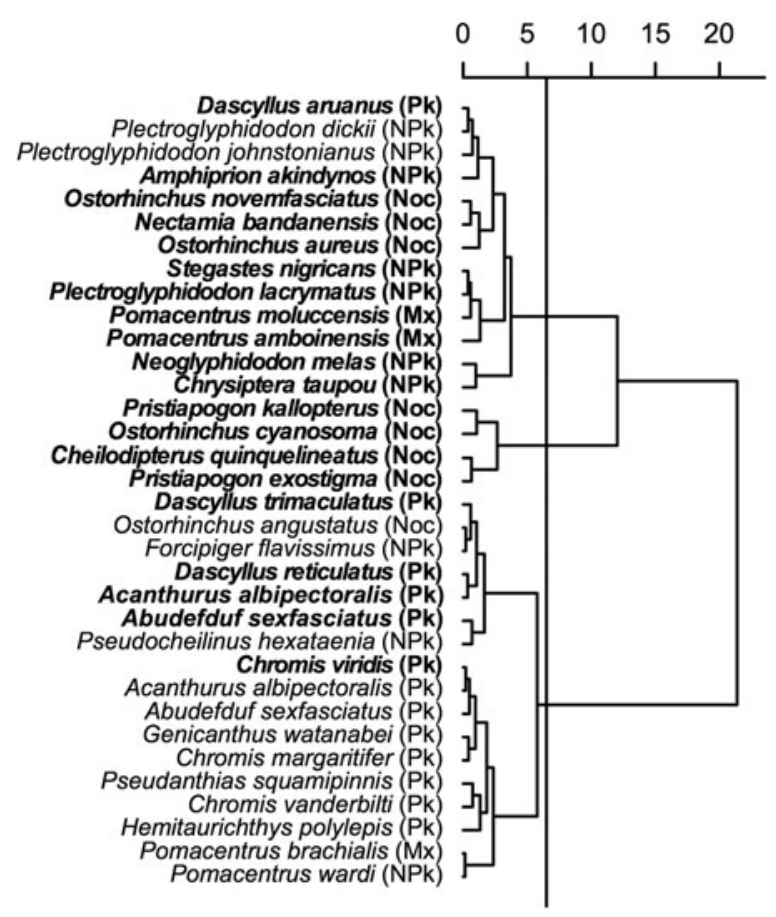

Fig. 3. Cluster analyses (Euclidean distance) of $d^{15} \mathrm{~N}$ and $d^{13} \mathrm{C}$ in teleost species sampled inside the Ouano lagoon (bold text) and on the outer slope. Pk: diurnal planktivorous teleosts; NPk: non-planktivorous teleosts; Mx: teleosts with a mixed diet; Noc: nocturnal teleosts.

$d^{13} \mathrm{C}$ values of teleosts are partially due to $d^{13} \mathrm{C}$ values of $\mathrm{POM}$ and zooplankton in their respective sampling area. Similar results were obtained at Ningaloo Reef (Wyatt et al., 2012), with increasing $d^{13} \mathrm{C}$ values in teleosts from the outer slope to the lagoon. In contrast, in Moorea Island, $\mathrm{d}^{13} \mathrm{C}$ values of the teleost Steagastes nigricans decreased from the entrances of the bays to the coastal areas (Letourneur et al., 2013). This trend, however, follows the decreasing trend of $\mathrm{d}^{13} \mathrm{C}$ values in POM across the bays. These results suggest that the sampled teleosts mostly rely on local food resources, and that migrations between lagoon and ocean are at best scarce. This hypothesis is consistent with their sedentary and even territorial behaviour, and the limited home range of most coral reef teleosts (Sale, 1978; Ceccarelli, 2007; Nash et al., 2015). As a result, higher contribution of reef-derived materials to the diet of teleosts, and thus higher $d^{13} \mathrm{C}$ values, are expected in the lagoon in the different trophic groups. This phenomenon was observed for the planktivorous teleost Amblyglyphidodon indicus in the Red Sea. On oceanic reefs (steep-walled pinnacles rising from deep water), analysis of stable isotope ratios in this planktivorous species revealed that it exploits a food chain with planktonic basal sources. On shelf reefs (situated on the continental shelf, in water between 25 and $60 \mathrm{~m}$ depth), although it still relied mainly on plankton-based food chains, this teleost appeared to also exploit a food chain based on phytobenthos (McMahon et al., 2016). As in other trophic compartments, $\mathrm{d}^{15} \mathrm{~N}$ values of teleosts did not differ between lagoon and outer slope and computed trophic levels appear to be similar. This result is consistent with the lack of spatial variations of $d^{15} \mathrm{~N}$ values in POM and zooplankton but differs from the results at Ningaloo Reef where $d^{15} \mathrm{~N}$ values of teleosts 
declined across the reef despite the lack of spatial variation of $\mathrm{d}^{15} \mathrm{~N}$ in POM (Wyatt et al., 2012, 2013). By using Bayesian mixing models with zooplankton, phytobenthos and coral mucus as prey, Wyatt et al. (2012) conclude that the contribution of zooplankton to the diet of teleosts decreased across the reef because of the rarity of oceanic zooplankton in the lagoon. Consequently, spatial variations of $d^{15} \mathrm{~N}$ at least in the diurnal planktivorous teleosts would have been expected if the zooplankton contribution to their diet had declined from the ocean to the lagoon. Nevertheless, because densities of zooplankton are higher or similar in lagoons than in ocean in south-western New Caledonia (Champalbert, 1993) and this zooplankton appears to be reef-produced, enough zooplankton may be available for planktivorous teleosts inside the lagoon. As a result, the absence of difference in $d^{15} \mathrm{~N}$ values between teleosts of the lagoon and of the outer slope may reflect the absence of difference in $\mathrm{d}^{15} \mathrm{~N}$ values between zooplankton of the lagoon and of the outer slope.

$d^{13} \mathrm{C}$ and $d^{15} \mathrm{~N}$ values differed significantly among trophic groups of teleosts. These differences, however, are the result of one trophic group having higher stable isotope values than the other ones (nocturnal planktivorous teleosts for $d^{13} \mathrm{C}$ and diurnal planktivorous teleosts for $d^{15} \mathrm{~N}$ ). The unusually high $\mathrm{d}^{13} \mathrm{C}$ values of nocturnal planktivorous teleosts sampled inside the Ouano lagoon may be explained by the diets of several species. Indeed, Apogon exostigma, Cheilodipterus quinquelineatus and Ostorhinchus cyanosoma feed primarily on benthic prey, including small teleosts (Barnett et al., 2006), that are generally enriched in ${ }^{13} \mathrm{C}$ compared with POM (Briand et al., 2015). Furthermore, the nocturnal emergence of zooplankton (Roman et al., 1990) may also change $d^{13} \mathrm{C}$ values of zooplankton (Pitt et al., 2008), as the emerging organisms may rely on ${ }^{13} \mathrm{C}$-enriched sedimentary organic matter (Briand et al., 2015) rather than on POM during daylight. Thus, the nocturnal emergence of zooplankton may influence $d^{13} \mathrm{C}$ values of their predators and upper trophic levels. In the lagoon, three species of sampled nocturnal planktivorous teleosts had isotopic compositions similar to those of non-planktivorous teleosts. Isotopic analyses on diurnal and nocturnal samples of zooplankton and POM should be carried out to confirm the existence of two different trophic pathways between day and night.

Stomach contents of the teleosts sampled on the outer slope indicated that several trophic groups may feed on similar prey. For example, Genicanthus watanabei fed mainly on phytobenthos like non-planktivorous teleosts. Such a phenomenon, already observed for the Genicanthus genus (Randall, 1975; Howe, 1993), may indicate that the trophic groups may have greater trophic plasticity or a less specific diet than indicated by stable isotopes. Further studies on the food web of the Ouano lagoon should also be done on stomach contents of teleosts sampled inside the lagoon in order to confirm the results presented here.

\section{CONCLUSIONS}

Differences in $d^{13} \mathrm{C}$ values between the lagoon and the outer slope show that the internal and external food chains are well differentiated between the Ouano Lagoon and the surrounding ocean, suggesting that exchanges of POM, phytoplankton and zooplankton between these biotopes are partially limited by the barrier reef and planktivorous teleosts.
Nevertheless, previous studies showed that open ocean particles may still be a source of carbon for lagoon food webs and that water passing over the barrier reef may resuspend benthic particles inside the lagoon. These two combined phenomena may lead to the differentiation of composition and thus $d^{13} \mathrm{C}$ values of POM between the lagoon and the outer slope. Consistent differences in $d^{13} \mathrm{C}$ values between the lagoon and the outer slope in each trophic compartment indicate reliance on POM by the two food chains. Furthermore, while the planktonic food chain on the outer slope of the Ouano lagoon probably relies more on oceanic sources, the planktonic food chain in the lagoon may rely on both oceanic (imported particles) and benthic (mucus aggregates and resuspended particles) sources because of tidal and wave induced external inputs and autochthonous releases. Consequently, bentho-pelagic coupling may occur in the Ouano Lagoon. The lack of spatial differences in $d^{15} \mathrm{~N}$ values of POM, zooplankton and teleosts, however, indicates a similar chain length in the lagoon and in the outer slope. Consequently, although distinguishable, the two food chains are similar.

The oceanic water typically passes over the barrier reefs in many lagoons. Consequently, this result is very likely to be generalizable on the general ecology of the trophic networks of many lagoons which are well separated from surrounding oceanic waters by a well delineated barrier reef.

\section{SU PPLEMENTARYMATERIAL}

The supplementary material for this article can be found at https://doi.org/10.1017/S0025315417001370

\section{ACKNOWLEDGEMENTS}

We would like to thank Claude Payri, for her welcome at the IRD centre of New Caledonia, and Pierre Labrosse and Olivier Boittiaux (High Commissioner of the Republic in New Caledonia), for allowing access to sampling zones. Thanks are also expressed to Samuel Tereua, pilot of the inflatable boat Diodon, and to Clément Pigot for preparing the samples. We are grateful to Gaël Guillou for running the stable isotope analyses. We also thank Michael Paul for improvement of the English. We thank the anonymous reviewers for their helpful comments.

\section{FINANCIALSUPPORT}

This work was funded by IRD for the M.I.O. Action Sud program.

\section{REFERENCES}

Barnett A., Bellwood D.R. and Hoey A.S. (2006) Trophic ecomorphology of cardinalfish. Marine Ecology Progress Series 322, 249-257.

Briand M.J., Bonnet X., Goiran C., Guillou G. and Letourneur Y. (2015) Major sources of organic matter in a complex coral reef lagoon: identification from isotopic signatures $\left(d^{13} \mathrm{C}\right.$ and $\left.\mathrm{d}^{15} \mathrm{~N}\right)$. PLOS ONE 10, e0131555. 
Briand M.J., Bonnet X., Guillou G. and Letourneur Y. (2016) Complex food webs in highly diversified coral reefs: insights from $d^{13} \mathrm{C}$ and $d^{15} \mathrm{~N}$ stable isotopes. Food Webs 8, 12-22.

Bunn S.E., Loneragan N.R. and Kempster M.A. (1995) Effects of acid washing on stable isotope ratios of $\mathrm{C}$ and $\mathrm{N}$ in penaeid shrimp and seagrass: implications for food-web studies using multiple stable isotopes. Limnology and Oceanography 40, 622-625.

Carassou L., Kulbicki M., Nicola T.J.R. and Polunin N.V.C. (2008) Assessment of fish trophic status and relationships by stable isotope data in the coral reef lagoon of New Caledonia, southwest Pacific. Aquatic Living Resources 21, 1-12.

Carleton J.H. and Doherty P.J. (1998) Tropical zooplankton in the highly-enclosed lagoon of Taiaro Atoll (Tuamotu Archipelago, French Polynesia). Coral Reefs 17, 29-35.

Ceccarelli D.M. (2007) Modification of benthic communities by territorial damselfish: a multi-species comparison. Coral Reefs 26, 853-866.

Champalbert G. (1993) Plankton inhabiting the surface layer of the southern and southwestern lagoon of New Caledonia. Marine Biology 115, 223-228.

Chevalier C., Devenon J.L. and Rey V. (2012) Impact of cross-reef fluxes on the Ouano lagoon circulation. In Yellowlees D. and Hughes T.P. (eds) Proceedings of the 12th International Coral Reef Symposium, Cairns, Australia, 9-13 July 2012. Townsville, Queensland: James Cook University, ICRS2012_4A_1.

Chevalier C., Sous D., Devenon J.L., Pagano M., Rougier G. and Blanchot J. (2015) Impact of cross-reef water fluxes on lagoon dynamics: a simple parameterization for coral lagoon circulation model, with application to the Ouano Lagoon, New Caledonia. Ocean Dynamics 65, 1509-1534.

Chisholm L.A. and Roff J.C. (1990) Size-weight relationships and biomass of tropical off Kingston, Jamaica. Marine Biology 106, 71-77.

Cortés E. (1997) A critical review of methods of studying fish feeding based on analysis of stomach contents: application to elasmobranch fishes. Canadian Journal of Fisheries and Aquatic Sciences 54, 726-738.

Crossman D.J., Choat J.H., Clements K.D., Hardy T. and McConochie J. (2001) Detritus as food for grazing fishes on coral reefs. Limnology and Oceanography 46, 1596-1605.

Cuet P., Atkinson M.J., Blanchot J., Casareto B.E., Cordier E., Falter J., Frouin P., Fujimura H., Pierret C., Susuki Y. and Tourrand C. (2011) CNP budgets of a coral-dominated fringing reef at $\mathrm{La}$ Réunion, France: coupling of oceanic phosphate and groundwater nitrate. Coral Reefs 30, 45-55

Davenport S.R. and Bax N.J. (2002) A trophic study of a marine ecosystem off southeastern Australia using stable isotopes of carbon and nitrogen. Canadian Journal of Fisheries and Aquatic Sciences 59, 514-530.

de Brye B., de Brauwere A., Gourgue O., Delhez E.J. and Deleersnijder E. (2013) Reprint of water renewal timescales in the Scheldt Estuary. Journal of Marine Systems 128, 3-16.

Delesalle B. and Sournia A. (1992) Residence time of water and phytoplankton biomass in coral reeflagoons. Continental Shelf Research $12,939-949$

DeNiro M.J. and Epstein S. (1978) Influence of diet on the distribution of carbon isotopes in animals. Geochimica and Cosmochimica Acta 42, 495-506.

DeNiro M.J. and Epstein S. (1981) Influence of diet on the distribution of nitrogen isotopes in animals. Geochimica and Cosmochimica Acta 45, 341-351.

Dromard R.C., Bouchon-Navaro Y., Cordonnier S., Fontaine M.F., Verlaque M., Harmelin-Vivien M. and Bouchon C. (2013)
Resource use of two damselfishes, Stegastes planifrons and Stegastes adustus, on Guadeloupean reefs (Lesser Antilles): inference from stomach content and stable isotope analysis. Journal of Experimental Marine Biology and Ecology 440, 116-125.

Frédérich B., Fabri G., Lepoint G., Vandewalle P. and Parmentier E. (2009) Trophic niches of thirteen damselfishes (Pomacentridae) at the Grand Récif of Toliara, Madagascar. Ichthyological Research 56, $10-17$.

Friedlander A.M. and DeMartini E.E. (2002) Contrasts in density, size, and biomass of reef fishes between the northwestern and the main Hawaiian islands: the effects of fishing down apex predators. Marine Ecology Progress Series 230, 253-264.

Gottfried M. and Roman M.R. (1983) Ingestion and incorporation of coral-mucus detritus by reef zooplankton. Marine Biology 72, 211-218.

Hamner W.M., Colin P.L. and Hamner P.P. (2007) Export-import dynamics of zooplankton on a coral reef in Palau. Marine Ecology Progress Series 334, 83-92.

Hamner W.M., Jones M.S., Carleton J.H., Hauri I.R. and Williams D. McB. (1988) Zooplankton, planktivorous fish, and water currents on a windward reef face: Great Barrier Reef, Australia. Bulletin of Marine Science 42, 459-479.

Harmelin-Vivien M., Loizeau V., Mellon C., Beker B., Arlhac D., Bodiguel X., Ferraton F., Hermand R., Pillippon X. and Salen-Picard C. (2008) Comparison of $C$ and $N$ stable isotope ratios between surface particulate organic matter and microphytoplankton in the Gulf of Lions (NW Mediterranean). Continental Shelf Research 28, 1911-1919.

Hobson E.S. (1974) Feeding relationships of teleostean fishes on coral reefs in Kona, Hawaii. Fishery Bulletin 72, 915-1031.

Hobson K.A. (1999) Tracing origins and migration of wildlife using stable isotopes: a review. Oecologia 120, 314-326.

Houlbrèque F., Delesalle B., Blanchot J., Montel Y. and Ferrier-Pagès $C$. (2006) Picoplankton removal by the coral reef community of La Prévoyante, Mayotte Island. Aquatic Microbial Ecology 44, 59-70.

Howe J.C. (1993) A comparative analysis of the feeding apparatus in pomacanthids, with special emphasis of oesophageal papillae in Genicanthus personatus. Journal of Fish Biology 43, 593-602.

Jacquet S., Delesalle B., Torréton J.P. and Blanchot J. (2006) Response of phytoplankton communities to increased anthropogenic influences (southwestern lagoon, New Caledonia). Marine Ecology Progress Series $320,65-78$.

Jaschinski S., Hansen T. and Sommer U. (2008) Effects of acidification in multiple stable isotope analyses. Limnology and Oceanography: Methods 6,12-15.

Kennedy P., Kennedy H. and Papadimitriou S. (2005) The effect of acidification on the determination of organic carbon, total nitrogen and their stable isotopic composition in algae and marine sediment. Rapid Communications in Mass Spectrometry 19, 1063-1068.

Kolasinski J., Rogers K. and Frouin P. (2008) Effects of acidification on carbon and nitrogen stable isotopes of benthic macrofauna from a tropical coral reef. Rapid Communications in Mass Spectrometry 22, 2955-2960.

Lecchini D., Adjeroud M., Pratchett M.S., Cadoret L. and Galzin R. (2003) Spatial structure of coral reef fish communities in the Ryukyu Islands, southern Japan. Oceanologica Acta 26, 537-547.

Leichter J.L., Alldredge A.L., Bernardi G., Brooks A.J., Carlson C.A., Carpenter R.C., Edmunds P.J., Fewings M.R., Hanson K.M., Hench J.L., Holbrook S.L., Nelson C.E., Schmitt R.J., Toonen R.J., Washburn L. and Wyatt A.S.J. (2013) Biological and physical interactions on a tropical island coral reef: transport and retention processes on Moorea, French Polynesia. Oceanography 26, 52-63. 
Letourneur Y., Lison de Loma T., Richard P., Harmelin-Vivien M.L., Cresson P., Banaru D., Fontaine M.F., Gref T. and Planes S. (2013) Identifying carbon sources and trophic position of coral reef fishes using diet and stable isotope $\left(\mathrm{d}^{15} \mathrm{~N}\right.$ and $\left.\mathrm{d}^{13} \mathrm{C}\right)$ analyses in two contrasted bays in Moorea, French Polynesia. Coral Reefs 32, 10911102.

McMahon K.W., Thorrold S.R., Houghton L.A. and Berumen M.L. (2016) Tracing carbon flow through coral reef food webs using a compound-specific stable isotope approach. Oecologia 180, 809-821.

Michener R.H. and Kaufman L. (2007) Stable isotope ratios as tracers in marine food webs: an update. In Michener R. and Lajtha K. (eds) Stable isotopes in ecology and environmental science. Malden, MA: Blackwell Publishing, pp. 238-282.

Moberg F. and Folk C. (1999) Ecological goods and services of coral reef ecosystems. Ecological Economics 29, 215-233.

Nash K.L., Welsh J.Q., Graham N.A.J. and Bellwood D.R. (2015) Home-range allometry in coral reef fishes: comparison to other vertebrates, methodological issues and management implications. Oecologia 177, 73-83.

Pinkas L.M., Oliphant S. and Iverson I.L.K. (1971) Food habits of albacore, bluefin tuna and bonito in Californian waters. Fish Bulletin California Department of Fish and Game 152, 1-105.

Pitt K.A., Clement A.L., Connolly R.M. and Thibault-Botha D. (2008) Predation by jellyfish on large and emergent zooplankton: implications for benthic-pelagic coupling. Estuarine Coastal and Shelf Science 76, 827-833.

Post D.M. (2002) Using stable isotopes to estimate trophic position: models, methods, and assumptions. Ecology 83, 703-718.

Post D.M., Layman C.A., Arrington D.A., Takimoto G., Quatrochi J. and Montana C.G. (2007) Getting to the fat of the matter: models, methods and assumptions for dealing with lipids in stable isotope analyses. Oecologia 152, 179-189.

Randall J.E. (1975) A revision of the Indo-Pacific angelfish genus Genicanthus, with description of three new species. Bulletin of Marine Science 25, 393-421.

R Core Team (2013) R: a language and environment for statistical computing. Vienna: R Foundation for Statistical Computing. ISBN 3-900051-07-0, http://www.R-project.org/

Roman M.R., Furnas M.J. and Mullin M.M. (1990) Zooplankton abundance and grazing at Davies Reef, Great Barrier Reef, Australia. Marine Biology 105, 73-82.
Sale P.F. (1978) Coexistence of coral reef fishes - a lottery for living space. Environmental Biology of Fishes 3, 85-102.

Satapoomin S. (1999) Carbon content of some common tropical Andaman Sea copepods. Journal of Plankton Research 21, 2117-2123.

Schoeninger M.J. and DeNiro M.J. (1984) Nitrogen and carbon isotopic composition of bone collagen from marine and terrestrial animals. Geochimica and Cosmochimica Acta 48, 625-639.

Skinner M.M., Martin A.A. and Moore B.C. (2016) Is lipid correction necessary in the stable isotope analysis of fish tissues? Rapid Communications in Mass Spectrometry 30, 881-889.

Smith J.E., Hunter C.L. and Smith C.M. (2010) The effects of top-down vs bottom-up control on benthic coral reef community structure. Oecologia 163, 497-507.

Uye S. (1982) Length-weight relationships in important zooplankton from the Inland Sea of Japan. Journal of the Oceanographical Society of Japan 38, 149-158.

Veit-Köhler G., Guilini K., Peeken I., Quillfeldt P. and Mayr C. (2013) Carbon and nitrogen stable isotope signatures of deep-sea meiofauna follow oceanographical gradients across the Southern Ocean. Progress in Oceanography 110, 69-79.

Wyatt A.S.J., Lowe R.J., Humphries S. and Waite A.M. (2013) Particulate nutrient fluxes over a fringing coral reef: source-sink dynamics inferred from carbon to nitrogen ratios and stable isotopes. Limnology and Oceanography 58, 409-427.

Wyatt A.S.J., Waite A.M. and Humphries S. (2010) Variability in isotope discrimination factors in coral reef fishes: implications for diet and food web reconstruction. PLOS ONE 5, e13682.

and

Wyatt A.S.J., Waite A.M. and Humphries S. (2012) Stable isotope analysis reveals community-level variation in fish trophodynamics across a fringing coral reef. Coral Reefs 31, 1029-1044.

Correspondence should be addressed to:

B. Le Bourg

Université de Liège, Laboratory of Oceanology, MARE Centre, 4000 Liège, Belgium

email: baptiste.lebourg@doct.ulg.ac.be 
Supplementary material: The same but different: stable isotopes reveal two distinguishable, yet similar, neighbouring food chains in a coral reef

Baptiste Le Bourg, Yves Letourneur, Daniela Banaru, Jean Blanchot, Cristèle Chevalier, Gérard Mou-Tham, Benoit Lebreton, Marc Pagano

Table S1. Trophic groups of the 32 teleost species sampled in the Ouano lagoon and determined from the literature

\begin{tabular}{ll}
\hline Species & References \\
\hline Diurnal planktivorous & Fishbase \\
Acanthurus albipectoralis & Frédérich et al., 2009 \\
Abudefduf sexfasciatus & Hobson and Chess, 1978 \\
Chromis margaritifer & Hobson, 1974 \\
Chromis vanderbilti & Hobson, 1991 \\
Chromis viridis & Frédérich et al., 2009; 2010 \\
Dascyllus aruanus & Hobson and Chess, 1978; Zikova et al., 2011 \\
Dascyllus reticulatus & Frédérich et al., 2009 \\
Dascyllus trimaculatus & Fishbase \\
Genicanthus watanabei & Sano, 1989 \\
Hemitaurichthys polylepis & Fishbase \\
Pseudanthias squamipinnis & \\
Nocturnal planktivorous & Barnett et al., 2006 \\
Cheilodipterus quinquelineatus & Fishbase \\
Nectamia bandanensis & Fishbase \\
Ostorhinchus angustatus & Fishbase \\
Ostorhinchus aureus & Barnett et al., 2006 \\
Ostorhinchus cyanosoma & Fishbase \\
Ostorhinchus novemfasciatus & Barnett et al., 2006 \\
Pristiapogon exostigma & Fishbase \\
Pristiapogon kallopterus & \\
Non-planktivorous & Fishbase \\
Chrysiptera taupou & Hobson, 1974; Sano, 1989 \\
Forcipiger flavissimus & Chan, 2007 \\
Neoglyphidodon melas & Ho et al., 2009 \\
Plectroglyphidodon dickii & Hobson, 1974; Ho et al., 2009 \\
Plectroglyphidodon johnstonianus & Frédérich et al., 2009 \\
Plectroglyphidodon lacrymatus & Ceccarelli, 2007; Ceccarelli et al., 2013 \\
Pseudocheilinus hexataenia & Williams and Williams, 1986 \\
Stegastes nigricans & Letourneur et al, 1997; Hata and Umezawa, 2011 \\
Mixed diet & \\
Amphiprion akindynos & Galetto and Bellwood, 1994 \\
Pomacentrus amboinensis & McCormick, 2003 \\
Pomacentrus brachialis & Fishbase \\
Pomacentrus moluccensis & Pratchett et al., 2001; Fishbase \\
\hline
\end{tabular}


Table S2. Frequency of occurrence $(\% \mathrm{O})$, numerical percentage $(\% \mathrm{~N})$, weight percentage $(\% \mathrm{~W})$ and percentage of the index of relative importance (\%IRI) obtained in stomach contents of teleosts sampled outside the Ouano lagoon

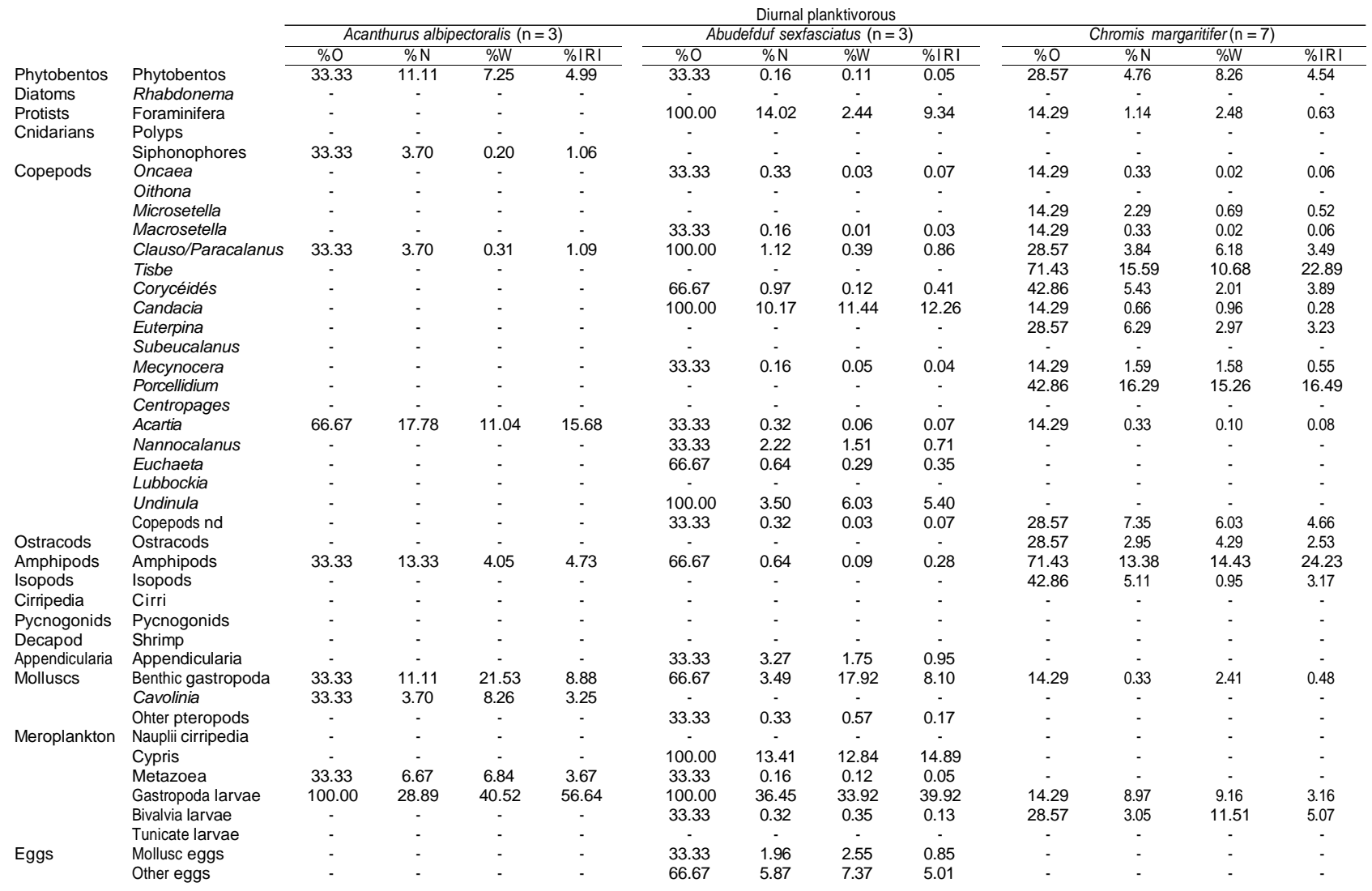

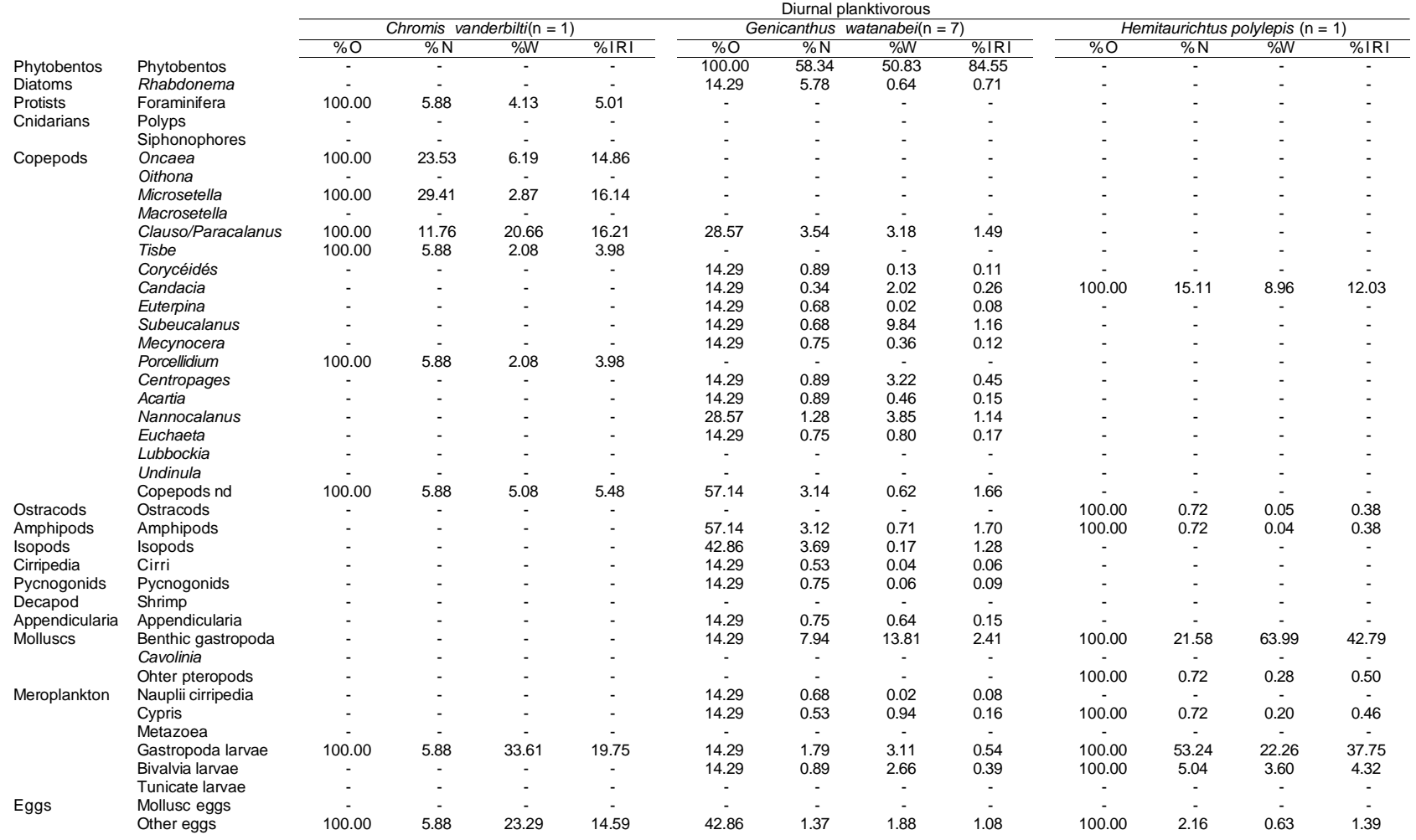


Table S2 (continued).

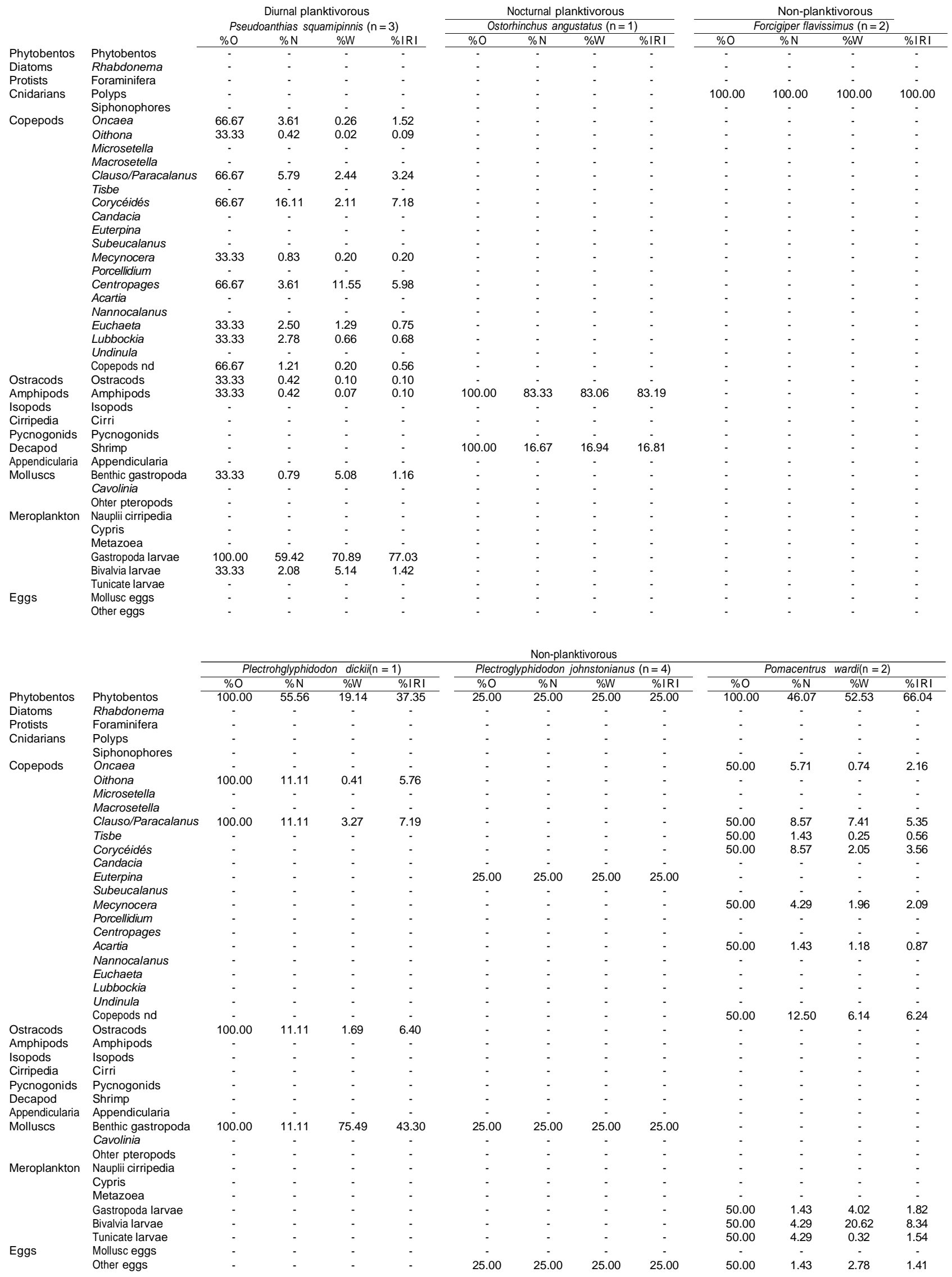


Table S2 (continued).

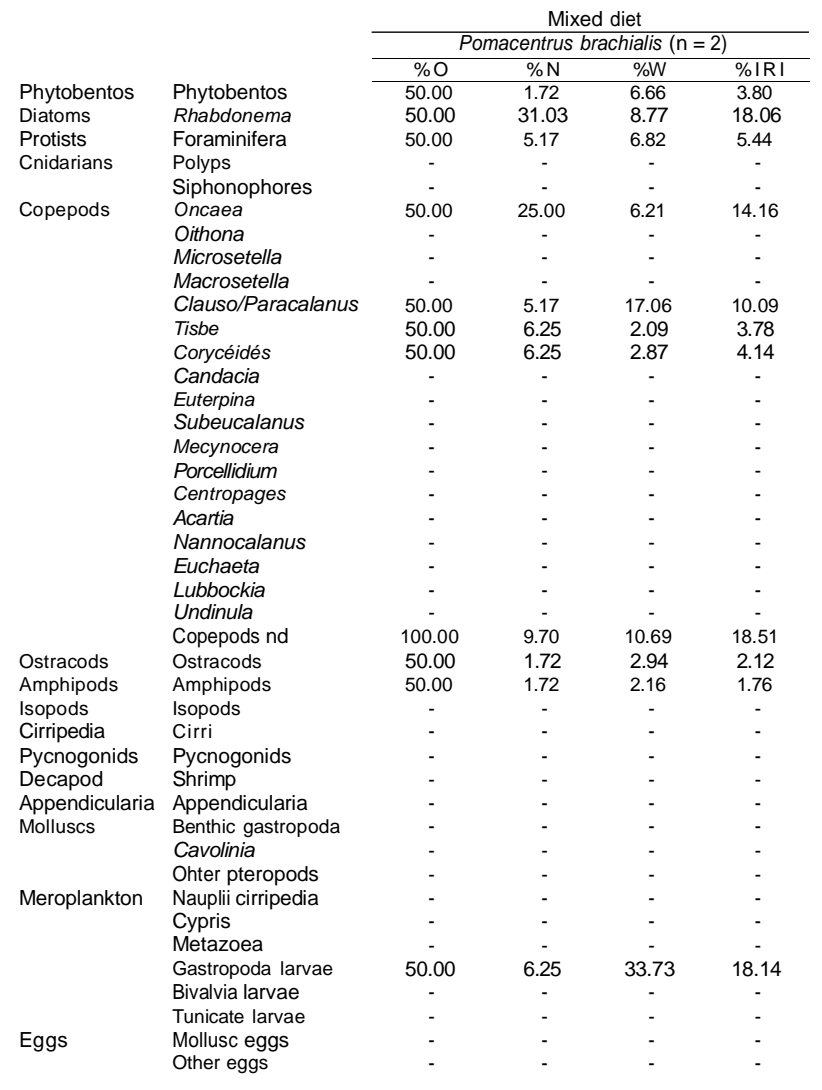

\section{References}

Barnett A., Bellwood D.R. and Hoey A.S. (2006) Trophic ecomorphology of cardinalfish. Marine Ecology Progress Series 322, 249-257.

Ceccarelli D.M. (2007) Modification of benthic communities by territorial damselfish: a multispecies comparison. Coral Reefs 26, 853-866.

Ceccarelli D.M., Emslie M.J. and Lewis A.R. (2013) Farming versatility by Pomacentrus wardi. Marine and Freshwater Research 64, 558-561.

Chan S.W. (2007) Ontogenetic Changes in Feeding Ecology and Habitat of the Damselfish Neoglyphidodon melas at Lizard Island, Great Barrier Reef. Independent Study Project (ISP) Collection. Paper 146.

Frédérich B., Fabri G., Lepoint G., Vandewalle P. and Parmentier E. (2009) Trophic niches of thirteen damselfishes (Pomacentridae) at the Grand Récif of Toliara, Madagascar. Ichthyological Research 56, 10-17.

Frédérich B., Lehanse O., Vandewalle P. and Lepoint, G. (2010) Trophic niche width, shift, and specialization of Dascyllus aruanus in Toliara Lagoon, Madagascar. Copeia 2, 218-226.

Galetto M.J. and Bellwood D.R. (1994) Digestion of algae by Stegastes nigricans and Amphiprion akindynos (Pisces: Pomacentridae), with an evaluation of methods used in digestibility studies. Journal of Fish Biology 44, 415-428.

Hatta H. and Umezawa Y. (2011) Food habits of the farmer damselfish Stegastes nigricans inferred by stomach content, stable isotope, and fatty acid composition analyses. Ecological Research 26, 809-818.

Ho C.T., Fu Y.C., Sun C.L., Kao S.J., and Jan R.Q. (2009) Plasticity of feeding habits of two Plectroglyphidodon damselfishes on coral reefs in southern Taiwan: evidence from stomach content and stable isotope analyses. Zoological Studies 48, 649-656.

Hobson E.S. (1974) Feeding relationships of teleostean fishes on coral reefs in Kona, Hawaii. Fishery Bulletin 72, 915-1031.

Hobson E.S. (1991) Trophic relationships of fishes specialized to feed on zooplankters above coral 
reefs. In Sale P.F. (ed) The ecology of fishes on coral reefs. Academy Press, Inc., pp 69-95.

Hobson E.S. and Chess J.R. (1978) Trophic relationships among fishes and plankton in lagoon at Enewetak Atoll, Marshall islands. Fishery Bulletin 76, 133-153.

Letourneur Y., Galzin R. and Harmelin-Vivien M. (1997) Temporal variations in the diet of the da mse lfish Stegastes nigricans (Lacepède) on a Réunion fringing reef. Journal of Experimental Marine Biology and Ecology 217, 1-18.

McCormick M.I. (2003) Consumption of coral propagules after mass spawning enhances larval quality of damselfish through maternal effects. Oecologia 136, 37-45.

Pratchett M.S., Gust N., Goby G. and Klanten S.O. (2001) Consumption of coral propagules represents a significant trophic link between corals and reef fish. Coral Reefs 20, 13-17.

Sano M. (1989) Feeding habits of Japanese butterflyfishes (Chaetodontidae). Environmental Biology of Fishes 25, 195-203.

Williams L.B. and Williams E.H. (1986) Ichthyological notes about fishes collected for parasite examination around Sesoko island, Okinawa. Galaxea 5, 217-221.

Zikova A.V., Britaev T.A., Ivanenko V.N. And Mikheev V.N. (2011) Planktonic and symbiotic organisms in nutrition of coralobiont fish. Journal of Ichthyology 51, 769-775. 